\title{
PEMBANGUNAN MODUL ROBOT PERMAINAN TOPIK RESPIRASI SEL MENGGUNAKAN MODEL ADDIE
}

\author{
${ }^{1}$ Muhamad Shakir bin Saad, ${ }^{2}$ Sabariah Sharif, ${ }^{3}$ Muralindran Mariappan \\ ${ }^{1,2}$ Fakulti Psikologi dan Pendidikan, Universiti Malaysia Sabah \\ ${ }^{3}$ Fakulti Kejuruteraan, Universiti Malaysia Sabah
}

Received : 25 Oktober 2017; Accepted : 03 Mac 2018; Published : 26 Jun 2018

\begin{abstract}
Abstrak
Tajuk respirasi sel mengandungi konsep dan fakta yang abstrak dan memerlukan pendekatan yang berbeza dalam proses pembelajaran bagi membolehkan para pelajar dapat mengaitkan konsep-konsep yang abstrak dalam bentuk pemahaman yang komprehensif. Ini membolehkan para pelajar dapat meningkatkan pencapaian dalam topik ini seterusnya dapat meningkatkan motivasi pelajar dalam meneruskan proses pembelajaran respirasi sel. Oleh itu, pengkaji telah membangunkan bahan pembelajaran robot berasaskan permainan dalam bentuk modul yang bukan sahaja sebagai platform untuk meningkatkan pencapaian malah kemahiran abad ke-21 dan motivasi pelajar. Modul pembelajaran ini akan menyediakan model konseptual bagi pembelajaran untuk meminimumkan keperluan untuk teknik pembelajaran konvensional yang bersifat verbal terutama dalam topik respirasi sel. Penyelidik telah membangunkan modul robot permainan respirasi sel menggunakan reka bentuk pengajaran ADDIE yang terdiri daripada fasa analisis, reka bentuk, pembangunan, pelaksanaan dan penilaian. Modul ini akan digunakan dalam kalangan pelajar matrikulasi kendalian Bahagian Matrikulasi Kementerian Pendidikan Malaysia (BMKPM)
\end{abstract}

Kata kunci Robot permainan, Respirasi sel, Abstrak, ADDIE, Matrikulasi.

\begin{abstract}
Respiration contains abstract concepts and facts and requires a different approach in the learning process to enable students to relate abstract concepts in comprehensive way. This allows students to improve their achievement in this topic, thereby enhancing students' motivation in pursuing the process of learning respiration. Therefore, I have developed a learning-based robot learning material in the form of modules that are not just as a platform to improve student achievement but also motivation and $21^{\text {st }}$ century skills of students. This modules will provide a conceptual model for learning and minimize the need for conventional verbal learning techniques especially for respirastion topic. Ihave developed a respiration robotic gaming module using the ADDIE teaching design which consists of the analysis, design, development, implementation and evaluation
\end{abstract}


PEMBANGUNAN MODUL ROBOT PERMAINAN TOPIK RESPIRASI SEL MENGGUNAKAN MODEL ADDIE

phases. This module will be used among the matriculation students of the Ministry of Education Matriculation Division (BMKPM)

Keywords Robot gaming, Respiration, Abstract, ADDIE, Matriculation.

\section{PENGENALAN}

ADDIE ialah nama singkatan bagi Analyze, Design, Develop, Implementation dan Evaluation. Falsafah pendidikan yang perlu diterapkan apabila model ADDIE digunakan ialah proses pembelajaran perlu berpusatkan pelajar, inovatif dan memberi inspirasi kepada para pelajar (Morrison, 2010). Model ADDIE boleh digunakan untuk menghasilkan alat bantu mengajar yang efektif khususnya berbantukan teknologi. Ini kerana model ini menyediakan panduan rangka kerja yang sistematik untuk disesuaikan dengan kepelbagaian situasi persekitaran pembelajaran (Gustafson \& Branch, 1997). ADDIE ialah proses yang mengaplikasikan konsep dan teori dalam isi kandungan yang spesifik (Dick \& Carey, 1996). Oleh hal demikian model ADDIE banyak digunakan oleh pendidik untuk menyediakan persekitaran pembelajaran yang membolehkan para pelajar membina sendiri pengetahuan dan kemahiran (Gustafson \& Branch, 1997).

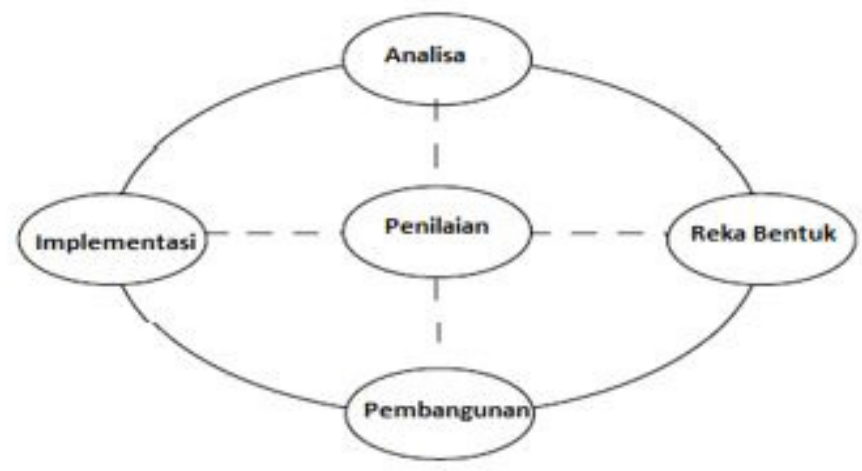

Rajah 1 Konsep ADDIE

Sumber: Morrison (2010).

ADDIE mengadaptasi input, proses dan output sebagai satu jalan untuk melengkapkan kesemua fasa (Dick \& Carey, 1996). Input akan bertindak balas dengan pemboleh ubah yang dikenal melalui penerimaan data, maklumat dan pengetahuan (Branch, 2009). Proses pula dilihat jalan untuk merangsang pemikiran kreatif dalam menggunakan prosedur, menterjemah serta menerangkan pelbagai pendekatan yang boleh digunakan dalam proses pembelajaran (Branch, 2009). Output menghantar keputusan daripada fasa proses dalam tindakan yang sewajarnya (Morrison, 2010). 


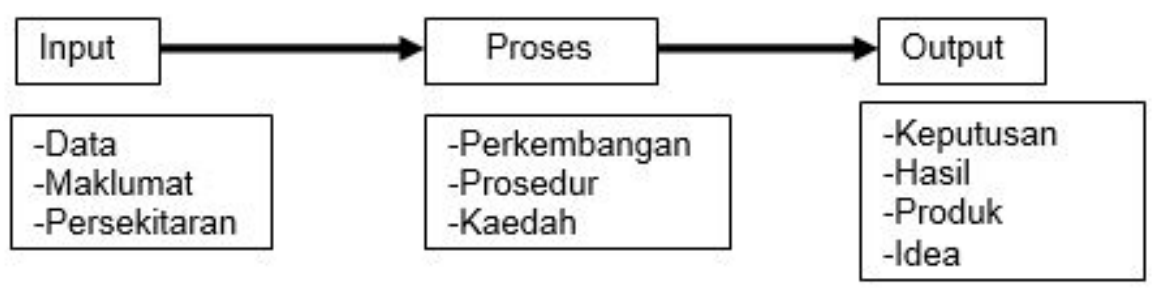

Rajah 2 Paradigma Input, Proses dan Output Sumber: Morrison (2010).

\section{PEMBANGUNAN MODUL}

Model ADDIE telah diserapkan dalam pembangunan modul robot permainan respirasi sel yang terdiri daripada fasa analisa, reka bentuk, pembangunan, pelaksanaan dan penilaian.

\section{ANALISA}

Tujuan fasa analisa ialah untuk mengenal pasti masalah yang menyebabkan terdapat jurang dalam pencapaian dari segi akademik. Menurut Branch (2009), fasa analisa melibatkan proses mengenal pasti perkara yang perlu dipelajari. Pada fasa ini, masalah pengajaran, tujuan dan objektif pembelajaran, pengetahuan dan kemahiran yang dimiliki oleh pelajar yang disasarkan dikenal pasti dengan teliti.

\section{a. Analisa Masalah Pengajaran}

Penyelidik telah mendapatkan hasil kajian tinjauan yang dilakukan oleh Azmizan (2014) yang menyatakan markah kuiz para pelajar Kolej Matrikulasi Kedah rendah dalam topik respirasi sel disebabkan para pelajar gagal untuk menghubungkan konsep-konsep respirasi sel kerana gagal mengingat sub topik tertentu dalam respirasi sel. Seterusnya Fazzlijan (2014) menggunakan perisian multimedia dalam proses pembelajaran dalam kalangan pelajar matrikulasi dalam topik respirasi sel yang dianggap sukar pada peringkat matrikulasi. Konsep yang abstrak dalam respirasi sel menyebabkan golongan kemampuan akademik rendah dan sederhana sukar untuk menguasainya. Pemilihan pelajar di matrikulasi mengikut piawai yang telah ditetapkan iaitu sekurang-kurangnya memperoleh gred B dalam Biologi di peringkat SPM. Justeru itu wujud jurang pencapaian di antara para pelajar yang memperoleh gred $\mathrm{A}+\& \mathrm{~A}$ (tinggi) dengan sederhana (A- dan ke bawah). Para pensyarah matrikulasi sukar untuk mereka bentuk proses pembelajaran kerana sukar untuk memenuhi kehendak pembelajaran yang berbeza di antara dua golongan ini atas kekangan masa.

\section{b. Analisa Sukatan Pelajaran Biologi PST Program Matrikulasi}

Pengkaji telah membuat analisis daripada sukatan pelajaran Biologi PST daripada ketua unit Kolej Matrikulasi Kedah. Sukatan pelajaran ini menuntut para pelajar 
PEMBANGUNAN MODUL ROBOT PERMAINAN TOPIK RESPIRASI SEL MENGGUNAKAN MODEL ADDIE

untuk menguasai proses- proses utama dalam respirasi sel iaitu glikolisis, kitar kreb dan rantaian pengangkut elektron yang kemudiannya mengaitkan dengan respirasi aerobik dan anaerobik.

\section{c. Temu bual}

Pengkaji telah menjalankan beberapa temu buat tidak berstruktur yang melibatkan 2 orang ketua unit Biologi, 2 orang pensyarah Biologi dan 3 orang pelajar matrikulasi untuk mengetahui masalah yang dihadapi bagi topik respirasi sel.

Jadual 1 Pihak Terlibat dalam Temu bual Fasa Analisis

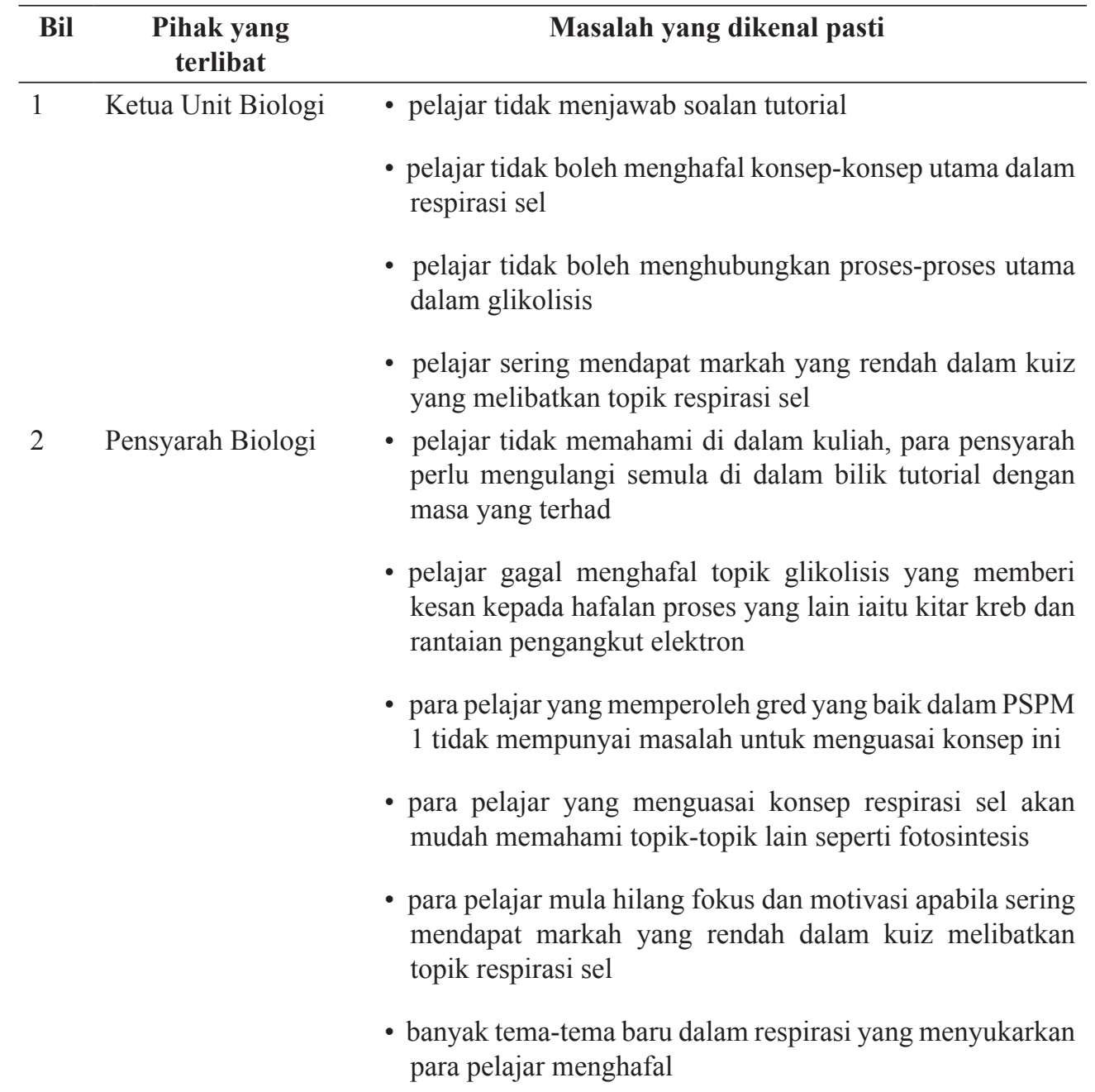




$\begin{array}{ll}\text { Pelajar Matrikulasi } & \text { - terlalu banyak untuk dihafal } \\ & \text { tidak faham di dalam kuliah dan mengharapkan pensyarah } \\ & \text { tutorial mengulangi semula di dalam kelas tutorial } \\ & \text { topik yang membosankan } \\ & \text { sering mendapat markah yang rendah menyebabkan hilang } \\ & \text { motivasi untuk mengusai konsep ini. }\end{array}$

d. Analisa Matlamat Modul

Meningkatkan skor pencapaian respirasi sel, kemahiran abad ke-21 (literasi komputer \& komunikasi berkesan) dan motivasi terhadap bahan pengajaran.

\section{e. $\quad$ Analisis Subjek Kajian}

Subjek kajian yang mengikuti kaedah pembelajaran robot permainan merupakan para pelajar matrikulasi modul 1\&3 melibatkan tiga kolej iaitu Kolej Matrikulasi Kedah, Kolej Matrikulasi Perak dan Kolej Matrikulasi Perlis. Ciri-ciri umum kumpulan pelajar yang disasarkan ialah mereka yang mengambil mata pelajaran Biologi di matrikulasi. Dalam kajian ini, hanya aspek perbezaan kebolehan akademik berbeza sahaja yang diambil kira dalam penilaian pengaruhnya terhadap pencapaian pelajar, kemahiran abad ke-21 dan motivasi terhadap bahan pengajaran. Berikut disenaraikan ciri-ciri pelajar daripada kumpulan sasaran adalah:

Umur :

Tahap pendidikan :

Kebolehan berbahasa Inggeris :

Motivasi Umum :

Kemahiran abad ke-21:

Pengalaman dalam topik :

Minat dalam topik :

Kemahiran menggunakan komputer:
18 -19 tahun

Matrikulasi (Pra Universiti)

Sederhana hingga tinggi

Sederhana hingga tinggi

Sederhana hingga tinggi

Peringkat pengenalan

Sederhana hingga tinggi

Boleh menggunakan persekitaran Windows dan tetikus dengan baik

\section{e. Analisis Sumber}

Terdapat tiga jenis bahan sumber yang perlu dikumpulkan iaitu (1) bahan sumber topik pelajaran (2) bahan sumber pembangunan pengajaran dan proses pembelajaran dan (3) sistem penyampaian pelajaran. Bahan-bahan sumber ini amat diperlukan untuk langkah-langkah seterusnya iaitu memahami isi kandungan, menjanakan idea dan mereka bentuk pengajaran. Bahan sumber yang diperoleh adalah seperti Jadual 2 
PEMBANGUNAN MODUL ROBOT PERMAINAN TOPIK RESPIRASI SEL MENGGUNAKAN MODEL ADDIE

Jadual 2 Bahan-Bahan Sumber Rujukan

\begin{tabular}{ll}
\hline Jenis Sumber & \multicolumn{1}{c}{ Topik pelajaran } \\
\hline Topik pelajaran & - Sukatan pelajaran Biologi Matrikulasi PST \\
& - Laporan Kerja Calon (LKC) PSPM 2 Semester 2 \\
& - Buku Bank Biologi Matrikulasi \\
& - Biology (Campbell) \\
& - Biology (Solomon) \\
& - Kain Kanvas (Medan permainan) \\
$\begin{array}{l}\text { Pembangunan } \\
\text { pengajaran dan } \\
\text { proses pembelajaran }\end{array}$ & - 50 Robot (daripada CERA) \\
& - Subject Matter Expect Biologi Matrikulasi \\
Sistem penyampaian \\
pelajaran
\end{tabular}

\section{Robot Comel dan Perisian S4A}

Pembangunan robot comel menggunakan otak Adruino Uno yang dilengkapi dengan sensor dan pengesanan menggunakan Bluetooh. Robot ini mampu menjalankan fungsi dan koordinasi yang hampir sama dengan Robot Lego, tetapi jauh lebih murah daripada pembelian Robot LEGO yang mencecah kos hampir RM 4500. Kos keseluruhan robot comel hanya RM 1000 dengan komponen-komponen yang berkualiti seperti Robot Lego. Robot Comel boleh diuraikan kepada komponenkomponen kecil dan dipasang semula secara fleksibel dan mudah.

Dalam kajian ini penyelidik tidak mendedahkan kepada para pelajar teknik pemasangan Robot Comel kerana kesuntukan masa pembelajaran di matrikulasi. Para pelajar hanya akan menggunakan robot dengan proses pengekodan robot menggunakan perisian S4A yang boleh didapati secara terbuka atas talian. Para pelajar hanya perlu memuat turun perisian ini yang jauh lebih ringkas bagi tujuan pengekodan robot jika dibandingkan dengan perisian kompleks yang lain seperti $\mathrm{C}++$. 


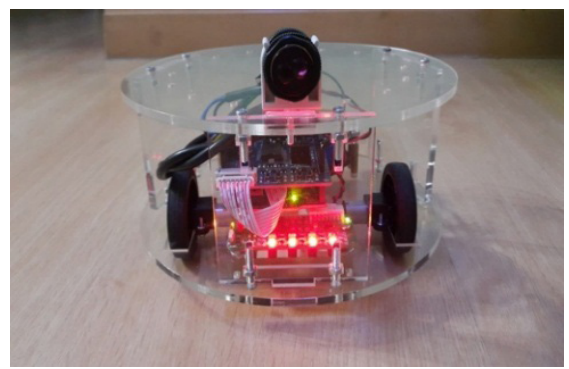

Rajah 3 Robot Comel

\section{REKA BENTUK}

Fasa reka bentuk ialah kaedah sistematik dalam merancang, membangunkan, menilai dan menguruskan proses pembelajaran (Morrison, 2010). Reka bentuk ini mesti selari dengan objektif pembelajaran serta sukatan pelajaran yang telah ditetapkan. Setelah selesai fasa reka bentuk ini, penyelidik dapat menyediakan proses pembelajaran yang spesifik bagi mengurangkan jurang pencapaian atas sebab yang telah dinyatakan dalam fasa analisa.

\section{a. Objektif Khusus}

Objektif khusus menggunakan modul ini dalam pembelajaran respirasi sel terdiri daripada:

1. Terdapat perbezaan skor min ujian pencapaian di antara kumpulan rawatan (robot permainan) dan kawalan (tradisional)

2. Terdapat perbezaan skor min kemahiran abad ke-21 di antara kumpulan rawatan (robot permainan) dan kawalan (tradisional)

3. Terdapat perbezaan skor min motivasi terhadap bahan pengajaran di antara kumpulan rawatan (robot permainan) dan kawalan (tradisional)

\section{b. $\quad$ Teori dan Model Terlibat Bagi Kaedah Robot Permainan}

Teori dan model ialah penting bagi merangka kaedah robot permainan topik respirasi sel. Dalam membangunkan kaedah robot permainan, satu perkaitan antara teori dan model telah dibincangkan dalam bab 2. Teori-teori yang dibincangkan kaitannya ialah:

1. Teori Pelaziman Operan

2. Teori Konstruktivisme Piaget

3. Teori Konstruktivisme Sosial Vygotsky

4. Teori Pemprosesan Maklumat

5. Teori Motivasi Jangkaan-Nilai

6. Model Motivasi ARCS

\section{c. $\quad$ Strategi Pelaksanaan Modul Robot Permainan Respirasi Sel}

Terdapat lima aspek yang dibincangkan bagi melaksanakan strategi pelaksanaan modul robot permainan respirasi sel iaitu pemilihan pensyarah, latihan pensyarah, sesi implementasi dan penilaian untuk pelajar. 


\section{i. Pemilihan Pensyarah}

18 orang pensyarah Biologi matrikulasi melibatkan tiga kolej matrikulasi iaitu Kolej Matrikulasi Kedah, Kolej Matrikulasi Perak dan Kolej Matrikulasi Perlis. 18 orang yang dilibatkan dalam kajian ini untuk mengajar subjek kajian topik respirasi sel ditunjukkan dalam jadual 4.3 berdasarkan kerelaan untuk terlibat dalam kajian ini. Jadual waktu pensyarah yang terlibat tidak terganggu dengan implementasi kajian mengambil waktu sebenar subjek Biologi yang telah ditetapkan oleh kolej masingmasing. Kesemua pensyarah ini mempunyai 12 jam waktu mengajar bagi seminggu yang terdiri daripada 8 jam kelas tutorial dan 4 jam amali. Langkah mengekalkan pensyarah yang sama di dalam kelas tutorial ini dapat menggelakkan rasa tidak selesa pelajar kerana mendapat seorang pensyarah yang baru. Ini kerana para pelajar perlu menyesuaikan diri dengan persekitaran yang bakal diwujudkan oleh pensyarah baru tersebut seterusnya mungkin menjejaskan hasil dapatan kajian. Kesemua pensyarah yang terpilih mempunyai sekurang-kurangnya 8 tahun pengalaman mengajar Biologi di Matrikulasi KPM, dan kesemuanya mempunyai ijazah sarjana muda dalam bidang pendidikan Biologi sebagai kelayakan minimum dan lapan orang mempunyai kelayakan ijazah sarjana pendidikan Biologi sebagai kelayakan paling tinggi. Ini menunjukkan latar belakang pengalaman mengajar dan tahap pendidikan pensyarah adalah setara. Penyelidik akan memberi taklimat berkaitan kajian kepada semua pensyarah terpilih ini di kolej masing-masing.

Jadual 3 Pensyarah Yang Dilatih Mengikut Kolej

\begin{tabular}{ccc}
\hline Kolej & Bilangan Pensyarah & Kaedah Mengajar \\
\hline Kolej Matrikulasi Kedah & 6 & $\begin{array}{c}\text { Tradisional } \\
\text { Robot Permainan } \\
\text { Tradisional } \\
\text { Kolej Matrikulasi Perak }\end{array}$ \\
Kolej Matrikulasi Perlis & 6 & $\begin{array}{c}\text { Robot Permainan } \\
\text { Tradisional }\end{array}$ \\
& 6 & Robot Permainan \\
\hline
\end{tabular}

\section{ii. Latihan Pensyarah}

Latihan yang diberikan kepada pensyarah selama 2 hari bertempat di kolej masingmasing. 6 jam diperuntukkan dalam sehari menjadikan jumlah 12 jam bagi latihan yang melibatkan 2 hari. Latihan ini mendapat kerjasama yang baik daripada pihak pengurusan kolej masing-masing dengan menyediakan tempat latihan yang kondusif. Latihan ini dibahagikan kepada tiga aspek utama iaitu teknikal, perisian S4A dan permainan robot. 
Jadual 4 Perincian Latihan Kepada Pensyarah

\begin{tabular}{llc}
\hline Aspek & \multicolumn{1}{c}{ Keterangan } & Bilangan Jam \\
\hline Teknikal & - menghidupkan butang buka robot & 2 jam \\
& - cara yang betul untuk mengecas robot & \\
& - pengenalan kepada komponen-komponen robot & \\
& - menghubungkan robot dengan perisian S4A di & \\
Perisian S4A & - pomputer menggunakan Bluetooth & 6 jam \\
& -hadapan & \\
& -belakang & \\
& -belok ke kiri & \\
& -belok ke kanan & \\
Permainan & -berpusing lawan jam & \\
robot & -berpusing arah jam & \\
\hline
\end{tabular}

\section{iii. Sesi Implementasi}

Kaedah robot permainan akan dilaksanakan di dalam kelas tutorial selepas para pelajar telah menjalani proses pembelajaran respirasi sel di dalam kuliah. Setiap kelas tutorial mengandungi 20 hingga 30 orang pelajar dan dibahagikan kepada 3 orang pelajar bagi setiap kumpulan. Modul bercetak akan disediakan kepada semua pensyarah bagi melicinkan proses pembelajaran robot permainan respirasi sel.

\section{iv. Penilaian}

Ujian pencapaian respirasi sel, soal selidik kemahiran abad ke-21 dan soal selidik motivasi pelajar akan digunakan untuk mengukur pencapaian, tahap kemahiran abad ke-21 (komunikasi berkesan \& literasi digital) dan motivasi pelajar. Pengukuran akan dilakukan sebanyak tiga kali melibatkan ujian pra, ujian pasca 1 dan ujian pasca 2.

\section{PEMBANGUNAN}

Fasa pembangunan merujuk kepada alat digunakan untuk mencipta bahan pembelajaran (Branch, 2009). Tujuan fasa ini ialah untuk menghasilkan serta mengesahkan sumber-sumber pembelajaran (Dick \& Carey, 1996). Setelah selesai fasa ini, penyelidik dapat mengenal pasti semua sumber yang diperlukan bagi proses pembelajaran yang telah dirancang. Hasil daripada fasa ini satu set lengkap yang komprehensif dapat dibentuk yang menyokong kepada proses pembelajaran. Selain itu juga aktiviti-aktiviti proses pembelajaran yang dibentuk ini dapat membantu pelajar untuk membina pengetahuan dan kemahiran. 
PEMBANGUNAN MODUL ROBOT PERMAINAN TOPIK RESPIRASI SEL MENGGUNAKAN MODEL ADDIE

\section{a. Membangunkan Manual Robot Permainan Respirasi Sel}

Manual robot permainan respirasi sel dibangunkan yang mengandungi 10 unit permainan. Setiap permainan mewakili proses-proses utama dalam respirasi sel iaitu glikolisis (3 permainan), kitar kreb (3 permainan) dan rantaian pengangkut elektron (3 permainan). Manual ini dilengkapi dengan panduan menggunakan modul, matlamat modul dan setiap perincian permainan bagi setiap tahap.

\section{b. Membangunkan Alat Ukur}

Pengkaji telah membangunkan satu instrumen ujian pencapaian respirasi sel dan dua soal selidik diadaptasi iaitu soal selidik kemahiran abad ke-21 untuk mengukur kemahiran abad ke-21 (komunikasi berkesan dan literasi digital) dan soal selidik motivasi pelajar terhadap bahan pembelajaran bagi mengukur motivasi pelajar.

\section{c. $\quad$ Membangunkan Aktiviti Permainan Respirasi Sel}

Terdapat satu aktiviti yang memerlukan pelajar mempelajari pengekodan robot menggunakan S4A dan sepuluh aktiviti permainan yang dibangunkan dalam modul robot permainan respirasi sel seperti ditunjukkan dalam jadual 5.

Jadual 5 Pengagihan Aktiviti Modul Robot Permainan Respirasi Sel

\begin{tabular}{clc}
\hline Unit & Nama Aktiviti & Proses Terlibat \\
\hline 1 & Robot dan S4A & Pengekodan Robot \\
2 & Glikolisis 1 & Susunan molekul \\
3 & Glikolisis 2 & Susunan struktur molekul \\
4 & Glikolisis 3 & Pemilihan molekul \\
5 & Kitar Kreb 1 & Susunan molekul \\
6 & Kitar Kreb 2 & Susunan struktur molekul \\
7 & Kitar Kreb 3 & Pemilihan molekul \\
8 & Rantaian Pengangkut Elektron 1 & Susunan laluan NADH \\
9 & Rantaian Pengangkut Elektron 2 & Susunan laluan FADH \\
10 & Rantaian Pengangkut Elektron 3 & Kenal pasti \\
\hline
\end{tabular}

Para pelajar perlu mempelajari cara pengekodan robot menggunakan perisian S4A bagi membolehkan robot bergerak ke hadapan, belakang, belok ke kiri (90 darjah) dan belok ke kanan (90 darjah). Kesemua pergerakan ini akan digunakan dalam permainan robot respirasi sel. Penyelidik telah membangunkan tatacara mudah (berperingkat) pengekodan dalam manual agar memudahkan para pelajar memahami konsep pengekodan menggunakan S4A. 
Jadual 6 Keterangan Permainan Tahap 1 dan 2

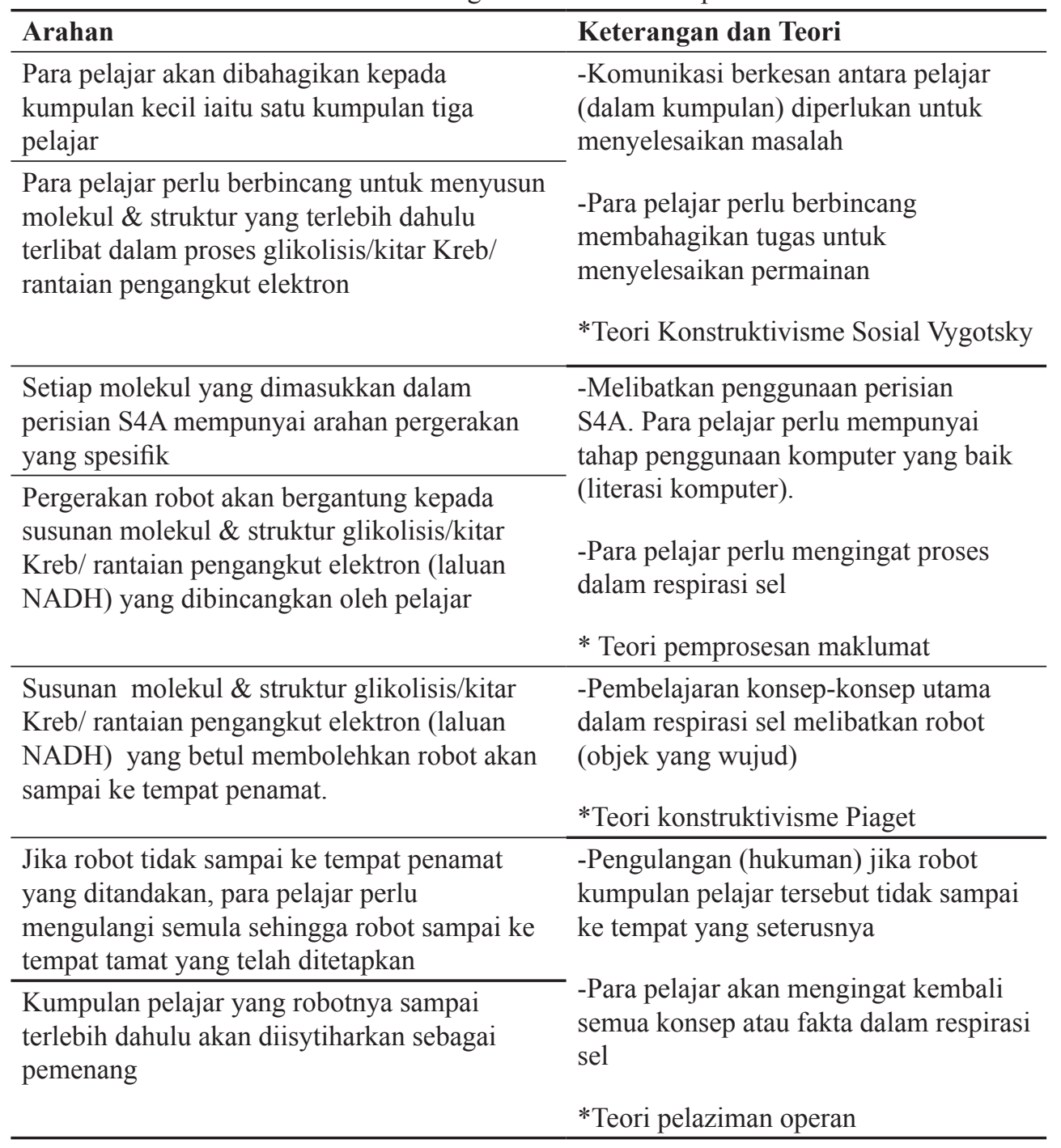

Jadual 7 Keterangan Permainan Tahap 3

\begin{tabular}{ll}
\hline Arahan & \multicolumn{1}{c}{ Keterangan dan Teori } \\
\hline $\begin{array}{l}\text { Para pelajar akan dibahagikan kepada kumpulan } \\
\text { kecil iaitu satu kumpulan tiga pelajar }\end{array}$ & $\begin{array}{l}\text {-Komunikasi berkesan antara pelajar } \\
\text { (dalam kumpulan) diperlukan untuk }\end{array}$ \\
\hline $\begin{array}{l}\text { Setiap kumpulan akan mendapat 10 kad } \\
\text { soalan (berdasarkan tajuk glikolisis) mewakili } \\
\text { perhentian-perhentian tertentu. }\end{array}$ & $\begin{array}{l}\text { menelesaikan masalah } \\
\text {-Para pelajar perlu berbincang } \\
\text { membahagikan tugas untuk } \\
\text { menyelesaikan permainan }\end{array}$ \\
& $*$ Teori konstruktivisme sosial Vygotsky \\
\hline
\end{tabular}




\begin{tabular}{ll}
\hline $\begin{array}{l}\text { Para pelajar akan memilih jawapan dan } \\
\text { pergerakan robot mewakili jawapan yang dipilih }\end{array}$ & $\begin{array}{l}\text {-Melibatkan penggunaan perisian } \\
\text { S4A. Para pelajar perlu mempunyai } \\
\text { tahap penggunaan komputer yang baik } \\
\text { Para pelajar perlu memilih laluan tersebut } \\
\text { (literasi komputer). }\end{array}$ \\
& $\begin{array}{l}\text {-Para pelajar perlu mengingat proses } \\
\text { dalam respirasi sel }\end{array}$ \\
& $*$ Teori pemprosesan maklumat \\
\hline $\begin{array}{l}\text { Jika para pelajar memilih jawapan yang salah } \\
\text { bagi setiap hentian, maka robot tidak akan }\end{array}$ & $\begin{array}{l}\text {-Pembelajaran konsep-konsep utama } \\
\text { sampai ke hentian yang sepatutnya. }\end{array}$ \\
$\begin{array}{ll}\text { (objek yang wujud) } \\
\text { Kumpulan pelajar yang robotnya sampai di } \\
\text { hentian yang betul dan paling pantas akan } \\
\text { diisytiharkan sebagai pemenang. }\end{array}$ & $\begin{array}{l}* \text { Teori konstruktivisme Piaget } \\
\text { kumpulan pelajar }\end{array}$ \\
& $\begin{array}{l}\text {-Para pelajar lebih fokus dalam } \\
\text { pembelajaran }\end{array}$ \\
& $*$ Teori pelaziman operan dan teori \\
\hline
\end{tabular}

\begin{tabular}{|c|}
\hline MOLEKUL \\
\hline PHOSPHOENLOPYRUVATE (PEP) \\
\hline $\begin{array}{c}\text { GLYCERALDEHYDE-3-PHOSPHATE \& } \\
\text { DHAP }\end{array}$ \\
\hline 1,3-BISPHOPHOGLYCERATE \\
\hline FRUCTOSE-1,6-BISPHOSPHATE \\
\hline GLUCOSE-6-PHOSPHATE \\
\hline FRUCTOSE-6-PHOSPHATE \\
\hline 3-PHOSPHOGLYCERATE \\
\hline PYRUVATE \\
\hline GLUCOSE \\
\hline 2-PHOSPHOGLYCERATE
\end{tabular}

\begin{tabular}{|c|}
\hline KOD \\
\hline 1 \\
\hline 2 \\
\hline 4 \\
\hline 5 \\
\hline 8 \\
\hline 9 \\
\hline 0 \\
\hline 3 \\
\hline 6 \\
\hline 7 \\
\hline
\end{tabular}

\begin{tabular}{|c|}
\hline ARAHAN \\
\hline TURNRIGHT (90 dariah) \\
\hline GO STRAIGHT ( 2.5 saat) \\
\hline GO STRAIGHT ( 2.5 saat $)$ \\
\hline TURN LEFT (90 darjah) \\
\hline TURN RIGHT (90 darjah) \\
\hline GO STRAIGHT ( 2.5 saat) \\
\hline TURN LEFT (90 darjah) \\
\hline REVERSE( 2.5 saat $)$ \\
\hline GO STRAIGHT (2.5 saat) \\
\hline GO STRAIGHT( 2.5 saat $)$ \\
\hline
\end{tabular}

SILA SUSUN MENGIKUT SUSUNAN MOLEKUL YANG HADIR TERLEBIHDAHULUDALAMPROSES GLIKOLISIS.

CONTOH : $6,7,8,9,0,1,2,3,4,5$

$5,4,3,2,1,0,9,8,7,6$ 


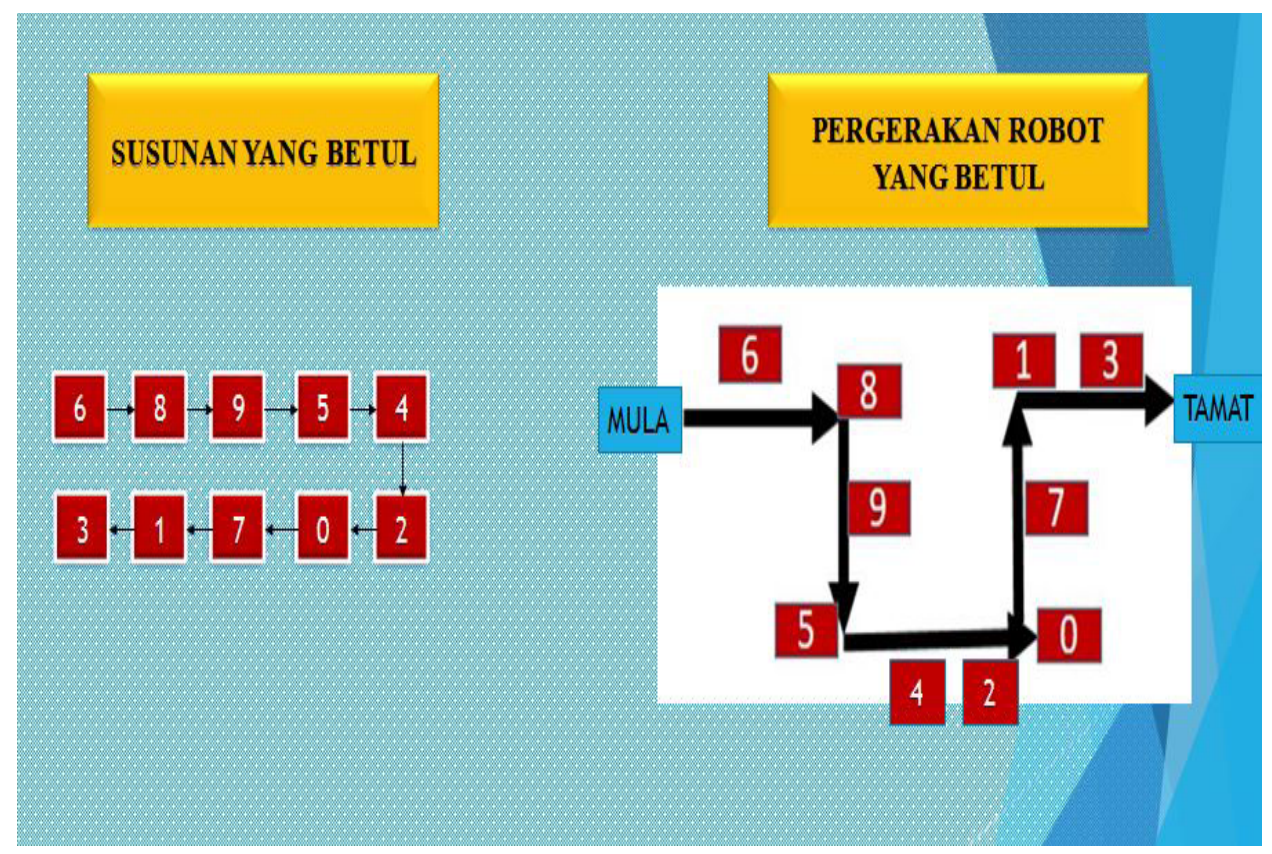

Rajah 4 Permainan Tahap 1

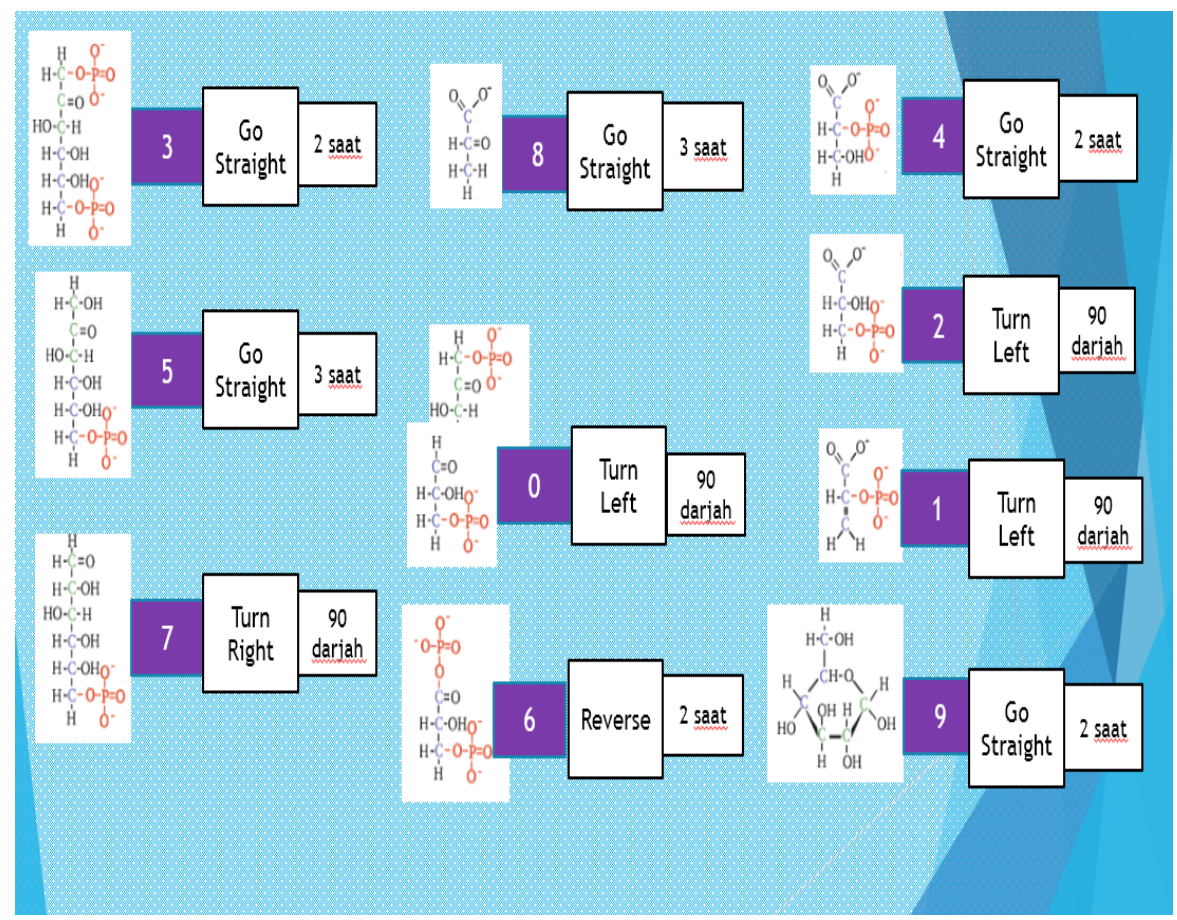




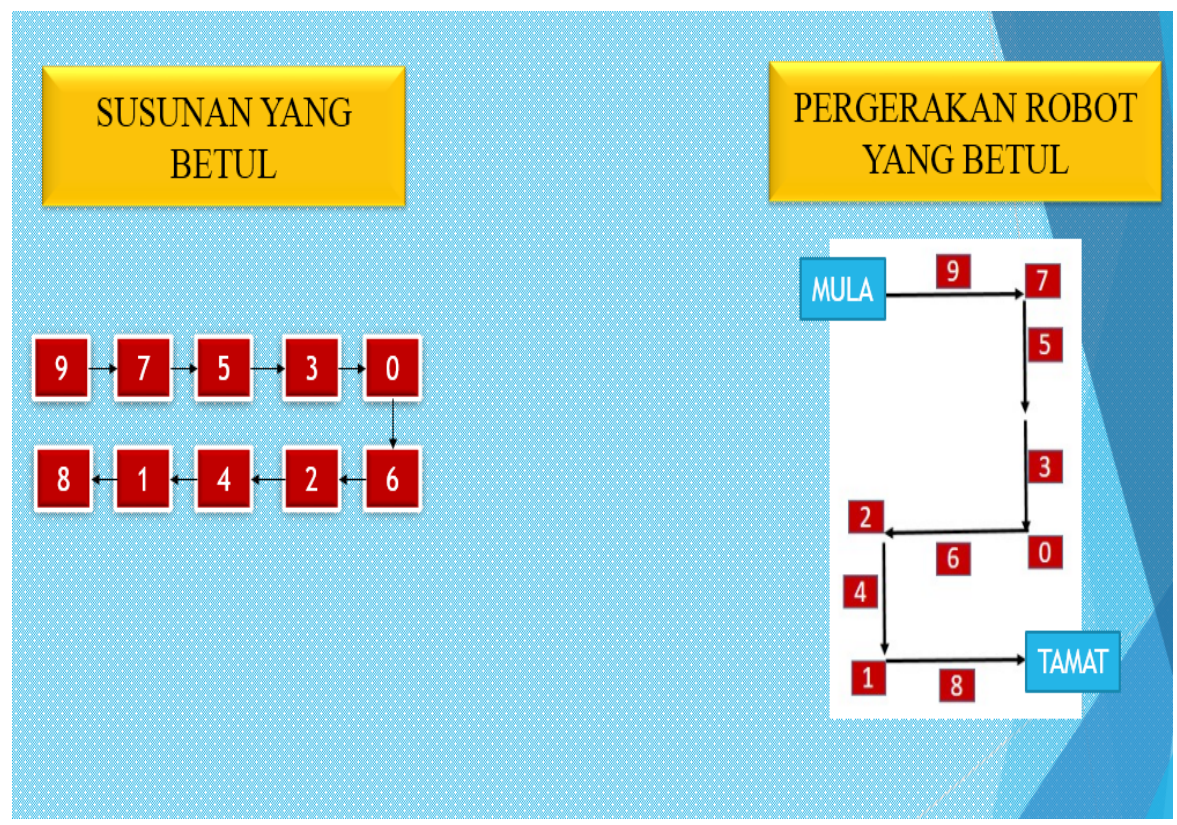

Rajah 5 Permainan Tahap 2

\begin{tabular}{|c|c|c|}
\hline No & Question & Direction \\
\hline 1 & How many net ATP produce in glycolysis? & $\begin{array}{l}\text { TURN RIGHT }=2 \\
\text { TURN LEFT=4 } \\
\text { GO STRAIGHT }=6\end{array}$ \\
\hline 2 & How many ATP produce in glycolysis? & $\begin{array}{l}\text { TURN RIGHT }=2=6 \\
\text { TURN LEFT }=4 \\
\text { GO STRAIGHT }=4\end{array}$ \\
\hline 3 & What process in qlycolysis produce ATP? & $\begin{array}{l}\text { TURN RIGHT= Substrate Level Phosphorylation } \\
\text { TURN LEFT=Oxidation } \\
\text { GO STRAIGHT=Phospohorylation }\end{array}$ \\
\hline 4 & What is the end products of glycolysis & $\begin{array}{l}\text { TURN RIGHT }=\text { ATP + Pyruvate + NADH } \\
\text { TURN LEFT }=2 \text { ATP + } 2 \text { Pyruvate + 2NADH } \\
\text { GO STRAIGHT=4ATP + 2Pyruvate+ } 2 \text { NADH }\end{array}$ \\
\hline 5 & Glycolysis occur in & $\begin{array}{l}\text { TURN RIGHT= Nucleus } \\
\text { TURN LEFT=Cytoplasm } \\
\text { GO STRAIGHT= Mitochondria }\end{array}$ \\
\hline 6 & Which step in glycolysis involve redox reaction? & $\begin{array}{l}\text { TURN RIGHT = PEP to Pyruvate } \\
\text { TURN LEFT= Glucose to Glucose-6-phosphate } \\
\text { GO STRAIGHT= G3P to 1,3-Bisphosphoglycerate }\end{array}$ \\
\hline 7 & Which step in glycolysis involve phosphorylation? & $\begin{array}{l}\text { TURN RIGHT = PEP to Pyruvate } \\
\text { TURN LEFT= G3P to 1,3-Bisphosphoglycerate } \\
\text { GO STRAIGHT=Glucose to Glucose-6-phosphate }\end{array}$ \\
\hline 8 & How many NAHD produce in glycolysis? & $\begin{array}{l}\text { TURN RIGHT }=1 \\
\text { TURN LEFT }=2 \\
\text { GO STRAIGHT }=3\end{array}$ \\
\hline 9 & $\begin{array}{l}\text { Which step in glycolysis involve substrate level } \\
\text { phosphorylation? }\end{array}$ & $\begin{array}{l}\text { TURN RIGHT= G3P to } 1,3-B i s p h o s p h o g l y c e r a t e \\
\text { TURN LEFT= PEP to Pyruvate } \\
\text { GO STRAIGHT= Fructose to Fructose-1,6-bisphophate }\end{array}$ \\
\hline 10 & What type of respiration involve glycolysis? & $\begin{array}{l}\text { TURN RIGHT= Aerobic Respiration } \\
\text { TURN LEFT= Aerobic Respiration \& Anaerobic Respiration } \\
\text { GO STRAIGHT= Anaerobic Respiration }\end{array}$ \\
\hline
\end{tabular}




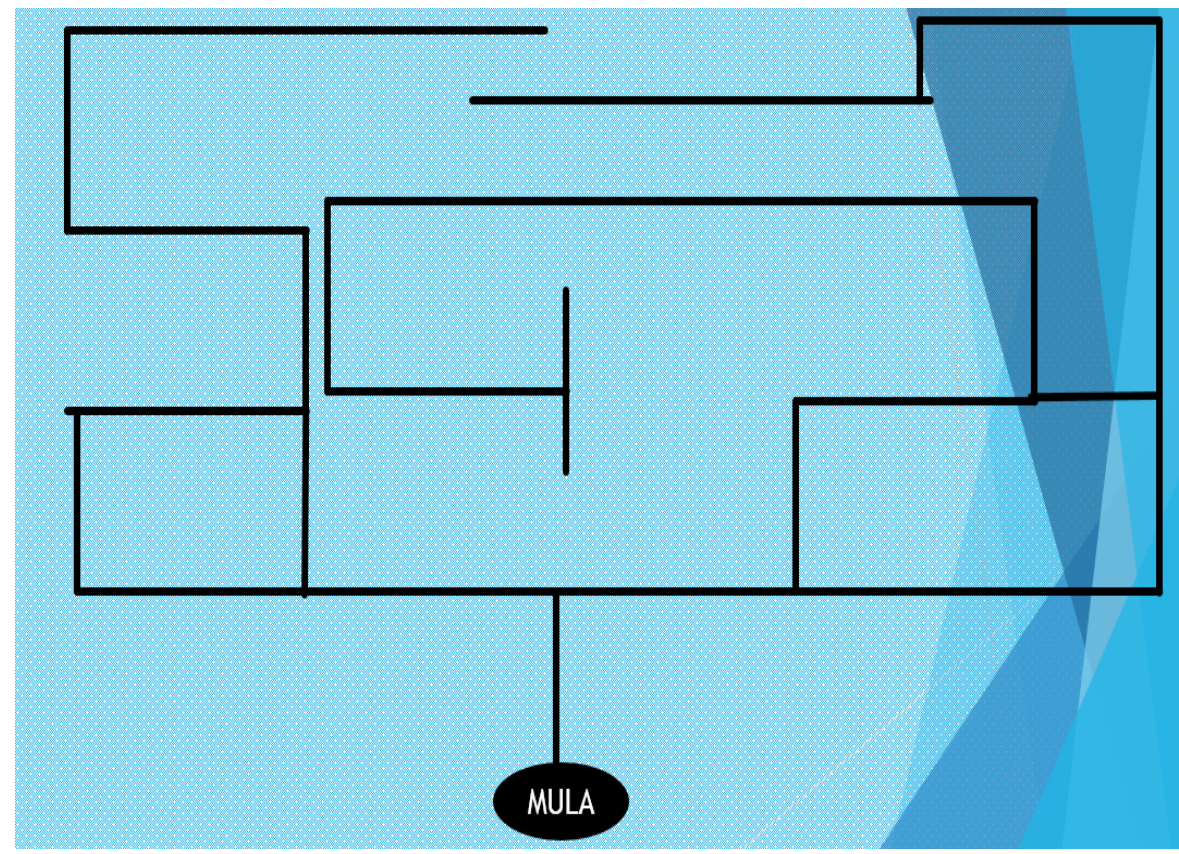

Rajah 6 Permainan Tahap 3

\section{PELAKSANAAN}

Tujuan fasa perlaksanaan ini ialah untuk menyediakan persekitaran pembelajaran yang mampu menampung proses pembelajaran yang telah dibangunkan (Branch, 2009). Fasa ini juga termasuk menyediakan para pelajar dan guru yang terlibat dalam proses pembelajaran ini (Dick \& Carey, 1996). Sebelum pelaksanaan sebenar dilakukan, kajian rintis penggunaan modul ini dilakukan di Kolej Matrikulasi Kelantan yang melibatkan 70 orang pelajar. Prosedur kajian mengambil masa 13 minggu tetapi intervensi hanya dilaksanakan selama sembilan minggu iaitu bermula pada minggu ke tiga hingga ke dua belas. Tempoh masa ini memadai kerana kajiankajian lepas berkaitan kajian yang bersifat kuasi eksperimen intervensi dilaksanakan dalam lingkungan 8 sehingga 16 minggu (Schimidt et al., 2009; Martin et al., 2008; Savin-Baden, 2008; Dogru \& Kalender, 2008). Ujian pra diberikan kepada semua pelajar pada minggu pertama, manakala ujian pasca 1 dilaksanakan pada minggu ke tiga belas serta ujian pasca 2 pada minggu ke empat belas.

\section{PENILAIAN}

Tujuan fasa penilaian ialah untuk menilai kualiti produk dan proses pembelajaran sebelum dan selepas proses implementasi (Morrison, 2010). Prosedur biasa dalam fasa penilaian ialah menentukan kriteria penilaian, memilih atau membangunkan alat penilaian seterusnya melakukan penilaian (Morrison, 2010). Komponen biasa dalam fasa penilaian ialah mengumpul dan menganalisis data berkaitan kriteria yang ingin dinilai. Kajian ini mempunyai tiga kriteria penilaian iaitu pencapaian, kemahiran 
abad ke 21 dan motivasi pelajar terhadap bahan pengajaran. Kriteria pencapaian dipilih oleh penyelidik kerana pencapaian akan menunjukkan kepada penyelidik sejauh mana kesan modul robot berasaskan permainan boleh memberi kesan kepada pemahaman pelajar terhadap konsep respirasi sel.

Selain itu juga kriteria kemahiran abad ke-21 merujuk kepada literasi komputer (penggunaan perisian S4A) \& komunikasi berkesan (aktiviti berkumpulan) serta motivasi pelajar terhadap bahan pembelajaran juga ingin dilihat dalam modul yang dibina ini. Justeru itu penyelidik telah membangunkan ujian pencapaian untuk menilai prestasi pelajar serta soal selidik kemahiran abad ke 21 yang diambil daripada Kamisah et al. (2012) dan soal selidik motivasi pelajar bahan pengajaran oleh Keller (1987).

\section{Kesahan dan Kebolehpercayaan Modul Robot Permainan}

Sidek Mohd Noah (1997) menyatakan bahawa kesahan sesuatu modul adalah usaha untuk mengukur isi kandungan. Modul robot permainan bertujuan untuk menerangkan konsep yang abstrak dalam respirasi sel. Justeru itu penentuan kesahan modul ini dengan menggunakan pandangan pakar seperti yang disarankan oleh Mohd Majid Konting (1998). Pengkaji menggunakan 3 orang khidmat pensyarah Matrikulasi DG (54) yang telah dilantik oleh BMKPM sebagai pensyarah subject matter expert dalam subjek Biologi sebagai tenaga pakar untuk memberikan respons kepada modul yang telah dibina. Ketiga-tiga pensyarah ini mempunyai pengalaman mengajar 23 tahun subjek Biologi pra universiti dengan 12 tahun telah berkhidmat dengan program matrikulasi BKPM. Penyelidik telah menggunakan soal selidik adaptasi daripada Sidek Mohd Noah (1997) untuk mendapatkan kesahan modul robot permainan ini. Untuk menentukan sama ada modul robot permainan ini mempunyai kesahan kandungan yang baik, maka pandangan Tuckman dan Waheed (1981) diambil kira yang menyatakan bahawa aras penguasaan atau pencapaian 70 peratus dianggap telah menguasai tahap pencapaian yang tinggi. Oleh hal demikian, modul dalam kajian ini akan dinilai berdasarkan nilai peratusannya dengan menggunakan formula berikut:

Jumlah skor pakar $\times \quad 100 \%=$ Pencapaian Kesahan Kandungan

Skor maksimum

Jadual 8 di bawah pula menunjukkan peratus persetujuan daripada penilaian panel pakar mengikut kriteria penilaian kesahan kandungan modul yang diberikan.

Jadual 8 Dapatan Kesahan Modul Robot Permainan Respirasi Sel

\begin{tabular}{llc}
\hline Bil & \multicolumn{1}{c}{ Pernyataan } & $\begin{array}{c}\text { Pencapaian Kesahan } \\
\text { Kandungan (\%) }\end{array}$ \\
\hline 1 & Kandungan modul ini menepati sasaran populasi & $90 \%$ \\
2 & $\begin{array}{l}\text { Kandungan modul ini boleh dilaksanakan dengan } \\
\text { sempurna }\end{array}$ & $80 \%$ \\
3 & $\begin{array}{l}\text { Kandungan modul ini bersesuaian dengan masa } \\
\text { yang diperuntukkan }\end{array}$ & $87 \%$
\end{tabular}


$4 \quad$ Kandungan modul ini boleh meningkatkan prestasi

$100 \%$

pencapaian pelajar

$5 \quad$ Kandungan modul ini boleh mengubah motivasi

$100 \%$

pelajar

6 Kandungan modul ini boleh meningkatkan

$93 \%$

kemahiran berkomunikasi pelajar

$7 \quad$ Kandungan modul ini boleh meningkatkan literasi

digital pelajar

$100 \%$

Russell (1974) menyatakan bahawa untuk menguji kebolehpercayaan sesuatu modul, pengkaji perlu melihat sejauh mana sampel (para pelajar) dapat mengikuti langkah-langkah setiap aktiviti di dalam modul dengan jayanya. Ini kerana setiap langkah-langkah aktiviti di dalam modul akan menentukan bahawa pelajar telah menguasai objektif modul tersebut. Oleh hal demikian, untuk menentukan nilai pekali kebolehpercayaan modul, item-item soalan boleh dicipta berdasarkan kepada langkah-langkah aktiviti modul tersebut. Justeru itu penyelidik akan membina empat soalan berdasarkan aspek teknikal dan objektif permainan bagi setiap permainan untuk menentukan nilai pekali kebolehpercayaan. Selain itu pada kajian rintis, penyelidik mengedarkan borang penilaian modul robot permainan respirasi sel seperti yang telah dicadangkan oleh Sidek Mohd Noah (1997). Jadual 9 menunjukkan nilai pekali kebolehpercayaan modul robot permainan respirasi sel hasil daripada kajian rintis yang dijalankan oleh penyelidik.

Jadual 9 Nilai Alpha Cronbach Modul Robot Permainan Respirasi Sel

\begin{tabular}{clcc}
\hline Unit & Tajuk & Alpha Cronbach & Bilangan Item \\
\hline 1 & S4A & .74 & 4 \\
2 & Glikolisis 1 & .80 & 4 \\
3 & Glikolisis 2 & .78 & 4 \\
4 & Glikolisis 3 & .78 & 4 \\
5 & Kitar Kreb 1 & .71 & 4 \\
6 & Kitar Kreb 2 & .70 & 4 \\
7 & Kitar Kreb 3 & .77 & 4 \\
8 & Rantaian Pengangkut Elektron 1 & .75 & 4 \\
9 & Rantaian Pengangkut Elektron 2 & .75 & 4 \\
10 & Rantaian Pengangkut Elektron 3 & .73 & 4 \\
& & Keseluruhan $=\mathbf{. 9 3}$ & $\mathbf{4 0}$ \\
\hline
\end{tabular}

Semua jenis permainan menunjukkan nilai Alpha Cronbach melebihi .70, manakala nilai keseluruhan ialah .96. Nilai ideal bagi kebolehpercayaan seharusnya melebihi 0.7 (Pallant, 2010). Justeru itu modul robot permainan respirasi sel ini mempunyai nilai kebolehpercayaan yang boleh diterima bagi meneruskan kajian. 


\section{RUMUSAN}

Bab ini telah menghuraikan tentang pembangunan modul robot permainan respirasi sel yang berlandaskan model reka bentuk pengajaran ADDIE. Penyelidik telah menjelaskan lima fasa dalam model ADDIE dan aplikasi dalam pembangunan modul robot permainan respirasi sel.

\section{RUJUKAN}

Azmizan Abdul Rahman. (2014). Analisa Kesukaran Topik Biologi Program Matrikulasi. Jabatan Sains. Kolej Matrikulasi Kedah. Changlun.

Branch, R. M. (2009). Instructional design: The ADDIE approach (Vol. 722). USA: Springer Science \& Business Media.

Dick, W., \& Carey, L. (1996). The Systematic Design of Instruction (4 ${ }^{\text {th }}$ Ed.). New York: Harper Collins College Publishers.

Dogru, F. \& Kalender, S. (2007). Applying the Subject Cell Through Constructivist Approach During Science Lessons and The Teacher's View. Journal of Environmental dan Science Education, 2(1), 3-13.

Fazzlijan Mohamad Ali Khan. (2014). Pembangunan dan Keberkesanan Perisian Multimedia Interaktif dengan Tiga Strategi Berbeza dalam Pembelajaran Respirasi Sel. Universiti Sains Malaysia, Pulau Pinang.

Gustafson, K., Branch, R.M. (1997). Instructional Design Models. NY: ERIC Clearinghouse on Information and Technology.

Kamisah Osman, Tuan Mastura Tuan Soh \& Nurazidawati Mohamad Arsad. (2012). M-21CSI: A Validated 21st Century Skills Instrument for Secondary Science Students. Asian Social Science, 8(16).

Keller, J.M. (1987). Strategies for stimulating the motivation to learn. Performance and Instruction, 26(8), 1-7.

Martin, L., West, J. \& Bill, K. (2008). Incorporating Problem-based Learning Strategies to Develop Learner Autonomy and Employability Skills in Sport Science Undergraduate. Journal of Hospitality, Leisure, Sport and Tourism Education, 7, 18-30.

Mohd Majid Konting. (1998). Kaedah Penyelidikan Pendidikan. $4^{\text {th }}$ ed. Kuala Lumpur: Dewan Bahasa Dan Pustaka.

Morrison, Gary R. (2010). Designing Effective Instruction, th $^{\text {th }}$ Edition. New York: John Wiley \& Sons.

Pallant, J. (2010). SPSS survival manual: A step by step guide to data analysis using SPSS (4th ed). Maidenhead: Open University Press/McGraw-Hill.

Rusell, J.D. (1974). Modular Instruction: A guide to the Design, Selection, Utilization and Evaluation of Modular Materials. New York: Publishing Company.

Savin-Baden, M. (2008). A Practical Guide to Problem-based Learning Online. London: Routhedge 
Schmidt, H.G., Van der Molen, H.T., Te Winkel, W.W.R., \& Winjen, W.H.F.W. (2009). Constructivist, Problem-based Learning Does Work: Meta-analysis of Curricular Comparisons Involving a Single Medical School. Educational Psychologist, 44 (4), 227-249.

Sidek Mohd Noah. (1997). Modul Penilaian dalam Kaunseling. Institut Pendidikan dan Pembelajaran Jarak Jauh (IDEAL). Serdang: UPM.

Tuckman, B.W, \& Waheed, M.A. (1981). Evaluating and individualized science programme for community college students. Journal of Research in Science Teaching, 18, 489-495. 